\title{
ENGINEERING CHARACTERISTICS OF ECO - FRIENDLY COMPOSITE MADE FROM STEEL SLAG - RICE HUSK AND GYPSUM
}

\author{
M. I. Morsy' ${ }^{1}$ and H. H. Mohamed ${ }^{2}$
}

\begin{abstract}
Steel slag waste is a by-product from steel production and rice husk is a renewable waste produced from rice peeling. These wastes can be used as Eco - Friendly building materials instead of polluting materials like gypsum and cement. The aim of this work is to investigate the behavior of building materials resulting from the mix of gypsum, steel slag and rice husk in different percentages.

The work was conducted in three phases. The first phase was conducted to investigate the effect of replacing gypsum by steel slag waste with different weight ratio (namely, 0, 10, 20, 30, 40, and 50\%) on the compressive strength of gypsum steel slag mixture at 1, 7, and 28 days. The second phase was conducted to investigate the water resistance of the developed gypsum steel slag mixture. The third phase was conducted to study the effect of addition of rice husk with different weight ratio ( 0, 5, $10,15,20,25 \%)$ to the highest strength of gypsum steel slag mixture, which optioned from last phases. Compressive strength, flexural strength, water absorption and density of the gypsum steel slag - rice husk mixtures were determined and investigated.
\end{abstract}

The results showed the highest compressive strength and water resisted for gypsum slag mixture that was at slag percent of 30\%. Also, compressive strength and density of gypsum steel slag rice mixture were reduced by increasing the rice husk content. The best rice husk content was $15 \%$ to enhance the flexural properties of steel slag - rice huskgypsum mixture binder.

Keywords: Gypsum, Steel lag, Rice husk, Engineering characteristics.

1- Lecturer, Agric.\& Biosystems Eng. Dept., Fac. of Agric. El-Shatby, Alexandria University, Egypt. 2- Lecturer, Soil \& Ag. Eng. Dept., Fac of Agric. Saba Basha, Alexandria University, Egypt. 


\section{INTRODUCTION}

onstruction materials cause a lot of environmental problems in the fabrication process such as cement. It is emits about one ton of $\mathrm{CO}_{2}$ into the air per each ton of cement. It is important to produce environmental friendly construction materials, which are structurally safe and durable. Gypsum is one of the most environmentally friendly binders, because the energy consumption for its production is substantially lower compared to the cement or lime and it can be also produced from many industrial waste products. It is also recyclable. Also, the friendly construction products depend on the use of alternative products as industrial wastes conventionally called green materials.

Gypsum binder which is also known as calcium sulfate semihydrate $\left(\mathrm{CaSO}_{4}-0.5 \mathrm{H}_{2} \mathrm{O}\right)$ is used in construction industry as a finishing material due to its ease of use, fire resistant, and environmentally friendly (Khalil et al 2018 and Zhu et al. 2018).

Also, gypsum binder has some limitations such as brittleness and low water resistance of its matrix that make it suitable for the interiors of buildings, and not for external applications (external plastering). (Weyeret al. 2015 and Henry et al. 2011).

Gypsum composite disadvantage can be improved by adding filler materials. Composite filler can be either organic or inorganic depending on the needed properties for the end product. Several researchers have reported the additions of some industrial and agricultural by-products, as a filler, to gypsum matrix to improve the water resistance properties, and the mechanical characteristics of gypsum-based composites (Sagnak 2018 and Riveraet al. 2012).

Riveraet al. (2012) reported that water resistance of gypsum composite increases by adding Portland cement or ground granulated blast furnace slag and the active mineral additives comprise amorphous silica. These additives lead to the formation of a dense, fine-crystalline structure of gypsum anhydrous matrix with finely dispersed amorphous new formations and improve the physical and mechanical properties of the binder.

The best results to obtain water resistant gypsum composite materials were achieved by the use of the composed binders with latent hydraulic 
and pozzolan materials (like ground granulated blast furnace slag, fly ash, and rice husk ash). Because pozzolan reaction needs the alkaline environment and gypsum is neutral or slightly acid, these binders have to contain some alkaline component (usually hydrated lime or cement). Such arterials are called ternary, because three main components create the binder (Pervyshin et al 2017).

Hekal et al. 2012 reported that steel slag is a by-product of the steel making process and has a complex chemical structure, consisting mostly of oxides and silicates that are formed as a result of the oxidation of various additives within the steel. Other slag products, such as blast furnace slag, coal slag, copper slag, etc, have been successfully utilized in civil construction works or producing abrasive materials and cements.

On the other hand, gypsum composite mechanical properties can be improved by using inorganic and organic fiber fillers. Polypropylene fibers are an example of inorganic fiber materials while the natural based materials such as natural fibers are the example of organic based fillers (Henry et al. 2011 and Selamat et al. 2019). Agricultural waste like waste paper, wheat straw, barley straw, rice straw, rice husk, cotton, flax, and oil palm trunk have been used as fillers to improve flexural and compressive strength of gypsum composites. It was given that agricultural waste fibers have higher tensile strength, less abrasiveness and lower cost compared to the inorganic reinforce material types of fillers (Abuh\&Umoh 2015, Ramesh et al. 2017, Hospodarova et al. 2018, Ashori 2017, and Selamat et al. 2019).

Saraswathy and Song (2007) reported that lot of researches have used rice husk as a rough material in industrialization as in civil engineering field, which has been widely used as additive to cement mixture due to beneficial pozzolanic effect.

Kim (2009) reported that rice husk and cork addition are good reinforcement materials for the production of the gypsum rice husk board and to obtain high insulation gypsum building material. The gypsum-rice husk board modulus of rupture and the modulus of elasticity increased as rice husk contents increased until $30 \%$. The rice husk gypsum boards are suitable for use as an interior ceilings and walls. 
This study is aiming to evaluate the physical potential of incorporating different percentages of steel slag in the production of gypsum-based composite by investigating its effect on compressive strength, density, porosity and water resistance. Also, Rice husk is incorporated with gypsum steel slag composite to produce porous material for geotechnical engineering application where excellent drainage ability and lightweight characteristics are essential.

\section{MATERIALS AND METHODS}

This work was carried out to develop a green composite, eco-friendly material of gypsum with steel slag and rice husk.

\section{2-1 Materials:}

The materials used for this experiment are locally available, which illustrated as follow:

1- Gypsum was used as the base binder material. The main component of gypsum is $95 \%$ Calcium sulfate semihydrate $\left(\mathrm{CaSO}_{4}\right.$. $\left.0.5 \mathrm{H}_{2} \mathrm{O}\right)$. The gypsum was obtained from Sinai Gypsum Factory.

2- Steel slag is a steel production by-product, which is produced in the separation of the impurities from molten steel. The slag is a molten liquid consists of silicates and oxides solution, which solidifies upon cooling as shown in Fig. (1). The steel slag was obtained from Helwan Steel factory in Helwan City. The chemical composition ofgypsumandsteel slag were measured by X-ray fluorescence technique at the Faculty of Science laboratory, Alexandria University. The results are presented in Table (1).

Table 1: Constituent composition of steel slag and gypsum, \%.

\begin{tabular}{|l|l|l|l|l|l|l|l|l|}
\hline $\begin{array}{l}\text { Constituent } \\
\text { composition, } \%\end{array}$ & $\mathrm{Fe}_{2} \mathrm{O}_{3}$ & $\mathrm{SiO}_{2}$ & $\mathrm{CaO}$ & $\mathrm{Al}_{2} \mathrm{O}_{3}$ & $\mathrm{MgO}$ & $\mathrm{SO}_{3}$ & $\mathrm{Na}_{2} \mathrm{O}$ & Traces \\
\hline Gypsum & $\mathbf{0 . 0 4}$ & $\mathbf{0 . 2 3}$ & 32.7 & $\mathbf{0 . 0 9}$ & $\mathbf{0 . 4 2}$ & $\mathbf{4 3 . 6 8}$ & $\mathbf{0 . 0 3}$ & $\mathbf{2 2 . 8 1}$ \\
\hline Steel Slag & $\mathbf{2 8 . 1 4}$ & $\mathbf{1 1 . 4 1}$ & 41.27 & $\mathbf{1 . 6 2}$ & $\mathbf{8 . 2 4}$ & $\mathbf{0 . 4 1}$ & $\mathbf{0 . 0 3}$ & $\mathbf{8 . 8 8}$ \\
\hline
\end{tabular}

3- Rice husk was obtained from Rice Research and Training Center, Alexandria as shown in Fig. (2).

4- A clean tap water was used during this experiment.

\section{2-2 Work plan:}

The experiments were conducted into three groups as follows:

1- The first group was conducted to investigate the effect of replacing gypsum by steel slag waste of $(0,10,20,30,40$ and 50\%) on 
the compressive strength of steel slag gypsum mixture after curing times of 1,7 and 28 day as given in Table (2).

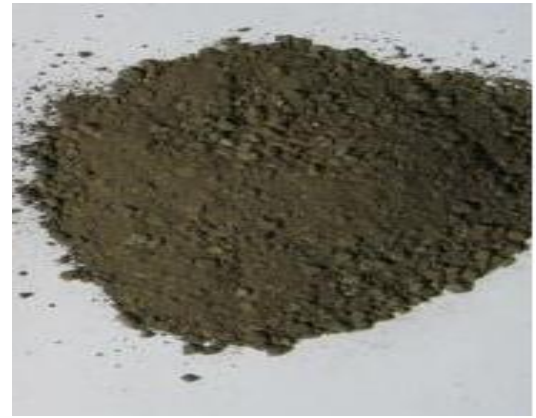

Fig. (1). Steel slag sample.Fig.

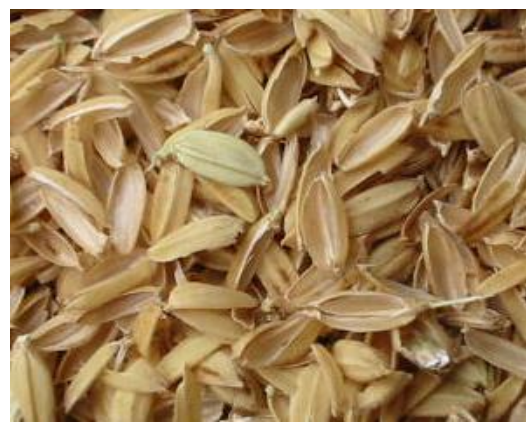

(2). Rice husk sample.

2- The second group was conducted to investigate the effect of immersion time of 1,7 and 28 day in water on the compressive strength of the above mention gypsum - steel slag mixes.

Table 2: Mixture proportions of Gypsum - Slag binder, by weight.

\begin{tabular}{|c|c|c|c|}
\hline Mix. & Gypsum, $\mathbf{g}$ & Steel slag, $\mathbf{g}$ & Water content, $\mathbf{g}$ \\
\hline G100 S0 & 1000 & 0 & 600 \\
\hline G90 S10 & 900 & 100 & 600 \\
\hline G80 S20 & 800 & 200 & 600 \\
\hline G70 S30 & 700 & 300 & 600 \\
\hline G60 S40 & 600 & 400 & 600 \\
\hline G50 S50 & 500 & 500 & 600 \\
\hline
\end{tabular}

3- The third group was conducted to investigate the effect of mixing rice husk with the best percentage of gypsum steel slag mixture which showed the highest compressive stress, based on the results obtained from the first and second group experiments. The percents of rice husk were $(0,10,15$, 20 and $25 \%$ ) of the total weight of gypsum- steel slag mixture as shown in table (3).

\subsection{Methodology:}

\subsubsection{Preparation of Gypsum- Steel slag mixtures:}

Test specimens were prepared as follows:

A- The materials used for each mixture as given in tables (2) were weighed and mixed in dry condition for 3-4 minutes.

B- Water was added to the blender for improving the workability of mixing process. 
C- Mixing process was continued for about 2 minutes. The obtained mixtures were poured in a $(40 \times 40 \times 160 \mathrm{~mm})$ mold as shown in Fig. (3). Molds were completely covered with plastic sheets to avoid any loss of water evaporation.

D- Specimens were left at room temperature for the first 24 hours.

E- The specimens were removed from their moulds, after the 24 hours period.

F-The specimens of each mixture were divided into two groups, the first group was used to measure the compressive strength of dry mixture after 1,7 and 28 days, while the second group was left to cure at room condition in plastic bags for 27 days. After that, the second group specimens were soaked in water for 28 days. Compressive strength of soaked specimens were determined after soaking for 1,7 and 28 days from soaking.

Table 3: Proportions of gypsum -steel slag - rice husk mixture, by weight.

\begin{tabular}{|c|c|c|c|}
\hline Mix. & $\begin{array}{c}\text { Gypsum- steel } \\
\text { slag, }\end{array}$ & Rice husk,g & Water, $\mathbf{g}$ \\
\hline G1 & 1000 & 0 & 600 \\
\hline G2 & 950 & 50 & 610 \\
\hline G3 & 900 & 100 & 630 \\
\hline G4 & 850 & 150 & 650 \\
\hline G5 & 800 & 200 & 670 \\
\hline G6 & 750 & 250 & 700 \\
\hline
\end{tabular}

2.3.2 Preparation of Rice Husk - Gypsum- Steel slag mixtures:

The preparation of test specimens was done following the same steps in the preparation of gypsum- steel slag mixtures. Rice husk percentages of $0,5,10,15,20$ and $25 \%$ by weigh were added to the heights strength gypsum- steel slag mixture as given in table (3).

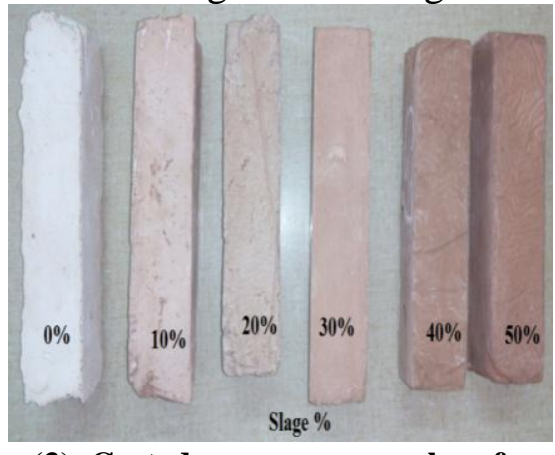

Fig. (3). Casted presumes samples of Gypsum - Slag binder.

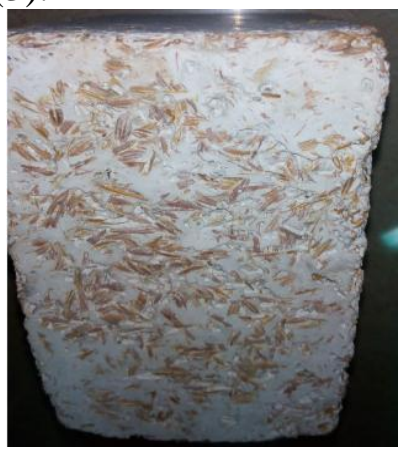

Fig. (4). Casted presume sample of Slag - Rice husk- Gypsum binder. 


\subsection{Mechanical tests}

\subsubsection{Compressive strength (CS)}

The compressive strength of the gypsum binder was tested according to European Standard (DIN EN 196-1). A servo hydraulic material testing system with a maximum capacity of $100 \mathrm{kN}$ was used to apply a constant loading rate test of $13.72 \mathrm{MPa}$ per min until failure. The testing machine was located in the lab of testing materials, Faculty of Engineering, Alexandria University. A cubic specimen of $40 \mathrm{~mm}$ dimension was used for each test. Three replicates of compressive strength tests were applied on specimens. The compressive strength (CS) was calculated as follows:

$$
\mathrm{CS}=\frac{\mathrm{Fu}}{\mathrm{W}^{2}}
$$

Where:

CS: Compression stress, MPa. $\quad$ Fu: Failure load, N.

W: Width of sample, mm.

\subsubsection{Flexural strength (FS)}

The flexural strength of the gypsum binder was carried out by the European standard (DIN EN 196-1) using a Universal Testing Machine. Beams of dimensions $40 \times 40 \times 160 \mathrm{~mm}$ were cast and then subjected to the three point Flexural test. Maximum load was measured to calculate Flexural strength after 28 days using the following formula for three point bending test:

$$
\mathrm{FS}=\frac{3 \mathrm{PL}}{2 \mathrm{BD}^{2}}
$$

Where:

FS: Flexural strength, MPa.

P: Maximum load, N.

L: Length of sample, $\mathrm{mm}$. B: Width of sample, $\mathrm{mm}$.

D: Thickness of sample, mm.

2.4.3. Softening index for gypsum mixture (SSI)

The softening index (SSI) for gypsum mixture was calculated to determine the effect of immersion time in water of gypsum binderon compression stress according to compression stress of dry sample.

The softening index for gypsum binder was calculated as follows: 


$$
\mathrm{SSI}=\frac{\mathrm{Csw}}{\mathrm{Csd}} \times 100
$$

Where:

SSI: Softening index for gypsum binder, $\%$.

Csw: Compression stress for immersed gypsum binder in water, MPa. Csd: Compression stress for dry gypsum binder, MPa.

\subsection{Physical properties}

\subsubsection{Bulk density}

For determination of hardened composite bulk density, a set of samples, each of dimensions $4 \times 4 \times 16 \mathrm{~cm}$ were tested. Three replicates of each sample were tested after 28 days of removing from the mold. All samples were dried at $105 \pm 5^{\circ} \mathrm{C}$ until a constant weight was achieved and then were placed in the air to cool down.

The weight and the volume based on the three basic dimensions of each dried specimen were measured. The bulk density was determined as follows:

$$
\rho_{\mathrm{b}}=\frac{\mathbf{W}_{\mathbf{d}}}{\mathbf{V}}
$$

Where:

$\boldsymbol{\rho}_{b}$ : Bulk density of the sample, $\mathrm{g} / \mathrm{cm}^{3} . \quad \mathbf{W}_{\mathbf{d}}$ : Weight of dry sample, $\mathrm{g}$. V : Volume of the sample, $\mathrm{cm}^{3}$.

\subsubsection{Water absorption test}

Three replicates were used for each test after 28 days. All samples were dried at $105 \pm 5^{\circ} \mathrm{C}$ until a constant weight was achieved. Water absorption was determined according to the American Standard Testing Method ASTM (D-1037) as follows: the dried specimens were weighed to the nearest 0.01 gram. The tested specimens were then soaked in water at room temperature for 24 hours. The specimens were hanged to drain the water for 10 minutes and the excess surface water was wiped. The specimen was weighed to the nearest 0.01 gram. The amount of water absorbed after 24 hours of soaking was calculated as a percentage of the original weight of test specimens.

$$
\mathrm{W}=\left(\frac{\mathrm{W}_{\mathrm{a}}-\mathrm{W}_{\mathrm{d}}}{\mathrm{W}_{\mathrm{d}}}\right) \times 100
$$


Where:

W : Water absorption, \%. Wa : Weight of saturated sample in air, $\mathrm{g}$. Wd : Specimen dry weight, g.

\section{RESULTS AND DISCUSSION}

\subsection{Effect of replacing gypsum by steel slag}

\subsubsection{Compressive strength (CS)of gypsum steel slag mixtures .}

The effect of replacing gypsum by steel slag waste of $(0,10,20,30,40$ and $50 \%$ ) on the compressive strength of mixture binder after curing time of 1, 7 and 28 day are shown in Fig.(5) and table. (4).

In general, the results showed that, the compressive strength (CS) for all tested hardened gypsum binder increases with the increase of slag from 0 to $30 \%$, while resulted in decreases compressive strength from $r \cdot$ to $0 . \%$. The maximum values of compressive strength were $1.77,4.33$ and 6.86 MPa for curing times of 1,7 and 28 day respectively at steel slag of $30 \%$, while the minimum values were $0.98,2.25$ and $3.23 \mathrm{MPa}$ for curing times of 1,7 and 28 days respectively at steel slag of $50 \%$.

A continuous increase in the compressive strength with curing time is due to the reduction of the porosity and the increase of the density of microstructure in gypsum binder by increase hydrating time. The best slag percent is $30 \%$ to make the highest compressive strength for steel slag gypsum binder.

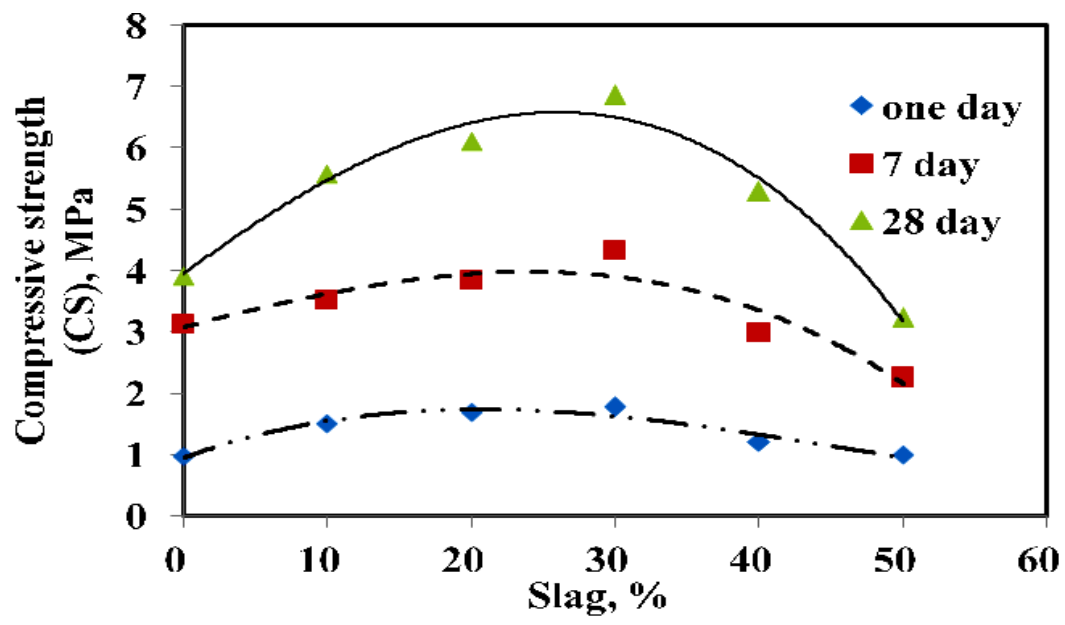

Fig. (5). Effect of slag, \% on compressive strength of gypsum binder. 
Table. (4). Effect of slag, \% on compressive strength of gypsum binder.

\begin{tabular}{|c|c|c|c|c|c|}
\hline \multirow{2}{*}{ Experiment } & \multirow{2}{*}{ Gypsum, \% } & \multirow{2}{*}{ Slag, \% } & \multicolumn{3}{|c|}{ Compressive strength, Mpa } \\
\cline { 4 - 6 } & & & $24 \mathrm{hr}$ & \multicolumn{3}{|c|}{$\begin{array}{c}\text { Curing time } \\
7 \text { day }\end{array}$} \\
\hline T1 & 100 & 0 & 0.98 & 3.14 & 3.92 \\
\hline T2 & 90 & 10 & 1.52 & 3.53 & 5.59 \\
\hline T3 & 80 & 20 & 1.70 & 3.84 & 6.11 \\
\hline T4 & 70 & 30 & 1.78 & 4.33 & 6.86 \\
\hline T5 & 60 & 40 & 1.21 & 2.99 & 5.30 \\
\hline T6 & 50 & 50 & 1.00 & 2.27 & 3.24 \\
\hline
\end{tabular}

3.1.2 Effect of immersion time in water on the compressive strength of gypsum steel slag mixtures .

The effect of immersion time of (1, 7 and 28 day) in water on the compressive strength of gypsum steel slag hardened mixtures for steel slag percentages of $(0,10,20,30,40$ and 50\%) are presented in Table (5) and Fig (6).In general the results showed that, the compressive strength for all tested gypsum binder increased with the increase of slag from 0 to $30 \%$, and resulted in decreases in compressive strength (CS) beyond 30 to $50 \%$ steel slag. The maximum values of compressive strength (CS) were 6.86, 6.77 and $6.7 \mathrm{MPa}$ at immersion time of 1, 7 and 28 day respectively for steel slag of $30 \%$. The minimum values of compressive strength were $3.25,2.38$ and $1.84 \mathrm{MPa}$ at immersion time of 1,7 and 28 day respectively for steel slag of zero \%.

Below 30\% slag, the highest compressive strength is the dry, while above $30 \%$ slag, the dry is the lowest.

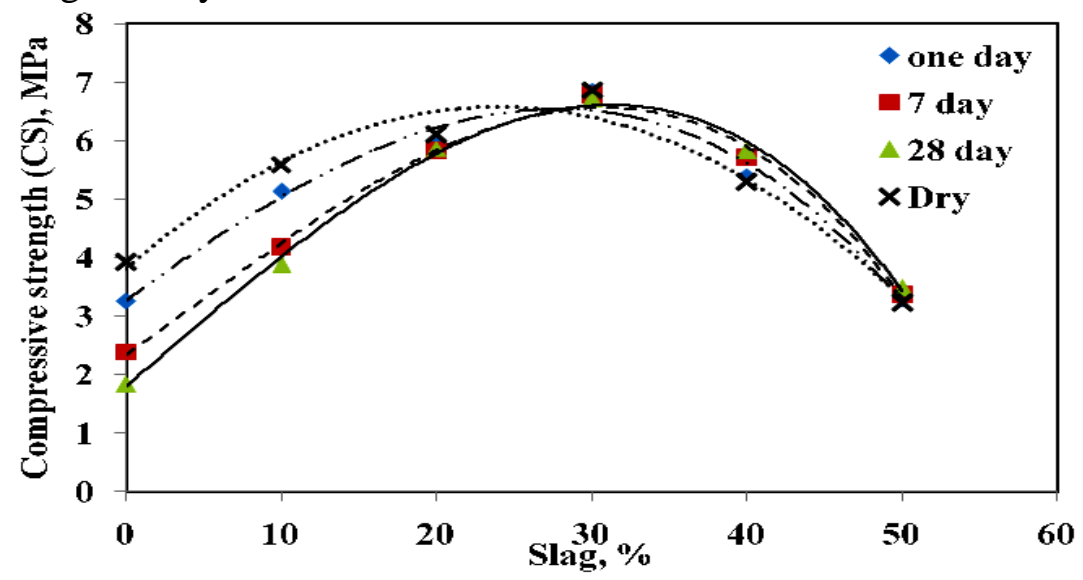

Fig. (6). Effect of immersion time on compressive strength of gypsum hardened binder. 
It was observed that all compressive strength values for different immersion times were converge at steel slag higher than $30 \%$ for gypsum hardened mixture. This may be due to increase of sample moisture resistanc by using steel slag higher than $30 \%$. The best slag percent is 30 $\%$ to make water resisted slag gypsum binder.

Table. (5). Effect of immersion time on compressive strength of gypsum hardened mixture.

\begin{tabular}{|c|c|c|c|c|c|}
\hline \multirow{2}{*}{$\begin{array}{c}\text { Gypsum, } \\
\%\end{array}$} & \multirow{2}{*}{ Slag, \% } & \multicolumn{4}{|c|}{ Compressive strength, Mpa } \\
\cline { 3 - 6 } & & Dry & \multicolumn{3}{|c|}{ Immersion tim e in water } \\
\cline { 3 - 6 } & 28 day & 24 hr & 7 day & 28 day \\
\hline 100 & 0 & 3.92 & 3.26 & 2.38 & 1.84 \\
\hline 90 & 10 & 5.59 & 5.13 & 4.18 & 3.88 \\
\hline 80 & 20 & 6.11 & 5.96 & 5.83 & 5.86 \\
\hline 70 & 30 & 6.86 & 6.86 & 6.78 & 6.71 \\
\hline 60 & 40 & 5.30 & 5.40 & 5.71 & 5.83 \\
\hline 50 & 50 & 3.24 & 3.30 & 3.37 & 3.48 \\
\hline
\end{tabular}

\subsubsection{Effect of immersion time on the softening index of gypsum mixtures.}

The effect of immersion time for 1, 7 and 28 days on softening index (SSI) of gypsum binder for slag percentages of $(0,10,20,30,40$ and 50\%) are shown in Fig (7).

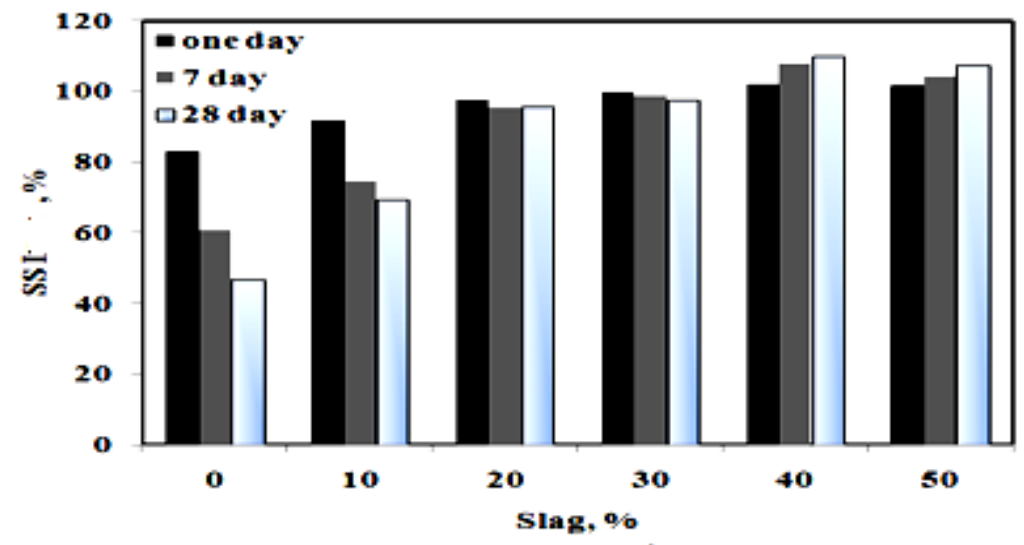

Fig. (7). Effect of immersion time on the softening index of gypsum mixtures.

In general, the results showed that, the SSI for all tested gypsum binder increases with the increase of slag from 0 to $50 \%$. It was observed that there are differences between SSI values at slag percentages of $(0,10$ and $20 \%$ ), while were the same at slag percentages of (30,40 and 50) for all immersion times. This is due to the increase in the sample moisture resists by using steel slag higher than $30 \%$. 


\subsection{Effect of gypsum-steel slag binder with rice husk}

\subsection{1 compressive strength and the flexural strength}

The effect of mixing rice husk of $(0,5,10,15,20$ and $25 \%$.) to gypsum steel slag of $30 \%$ on the compressive strength and the flexural strength of gypsum hardened binder after 28 day are presented in Fig (8).

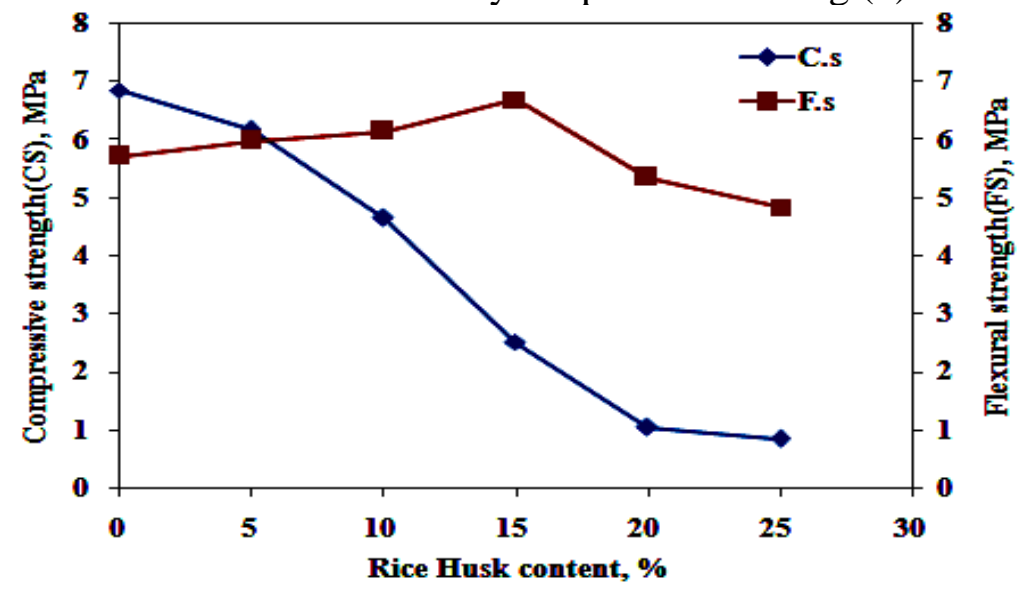

Fig. (8). Effect of rice husk, \% on the compressive strength and the flexural strength of steel slag gypsum binder after 28 day.

In general, results showed that, the compressive strength for all tested hardened gypsum mixture decrease with the increase of rice husk content. The maximum value of compressive strength was $6.86 \mathrm{MPa}$ for rice husk $0 \%$, while the minimum value was $0.84 \mathrm{MPa}$ for rice husk of $25 \%$. When $25 \%$ rice husk is added into the specimen mixture, the compressive strength is only $12 \%$ of the control sample, which is due to the porous nature of rice husk. The presence of higher amounts of rice husk changes the microstructure of gypsum mixture resulting in the production of low strength porous material. Also, rice husk absorbs a lot of water and this reduces the degree of compaction of the fresh mix resulting in presents of void and non-uniform distribution of rice husk. This condition explains the reduction of compressive strength with introduction of rice husk. On the other hand, The flexural strength for all tested hardened mixtures increases with the increase of rice husk from 0 to $15 \%$, while resulted in decreases flexural strength from 15 to $25 \%$ rice husk. The maximum value of flexural strength was $6.68 \mathrm{MPa}$ for rice husk $15 \%$, while the minimum value was $4.83 \mathrm{MPa}$ for rice husk of $25 \%$. When $15 \%$ rice husk is added into the specimen mixture, the flexural strength is improved by 
$17 \%$ of the control sample. The best rice husk content toenhance the flexural properties of gypsum-steel slag mixtures is up to $15 \%$.

3.2.2 Bulk density and water absorption:

The effect of adding rice husk $(0,5,10,15,20$ and $25 \%$.) to gypsumsteel slag mixture on the density and the water absorption are presented in Fig (9). In general, the results showed that, increasing rice husk from 0 to $25 \%$ for all tested hardened mixtures resulting in decreasing density.Since rice husk possess lower density compared to the other particle, the density of gypsum steel slag rice husk mixtures decreased with the increase of percentage of rice husk content. On the other hand, the addition of rice husk will cause increment in void and thus lower the density of the sample. The density of gypsum steel slag rice husk mixtures in this investigation ranges from $1.73 \mathrm{~g} / \mathrm{cm}^{3}$ at $0 \%$ rice husk content to 0.93 $\mathrm{g} / \mathrm{cm}^{3}$ at $25 \%$ rice husk content. The lowest density is given for $25 \%$ rice husk sample which is about $46 \%$ of the control sample. These results of density indicate that the gypsum steel slag rice husk mixture have a great potential to be applied in geotechnical field as lightweight material in order to minimize surcharge to the ground and also reducing the lateral pressure as lightweight backfill.

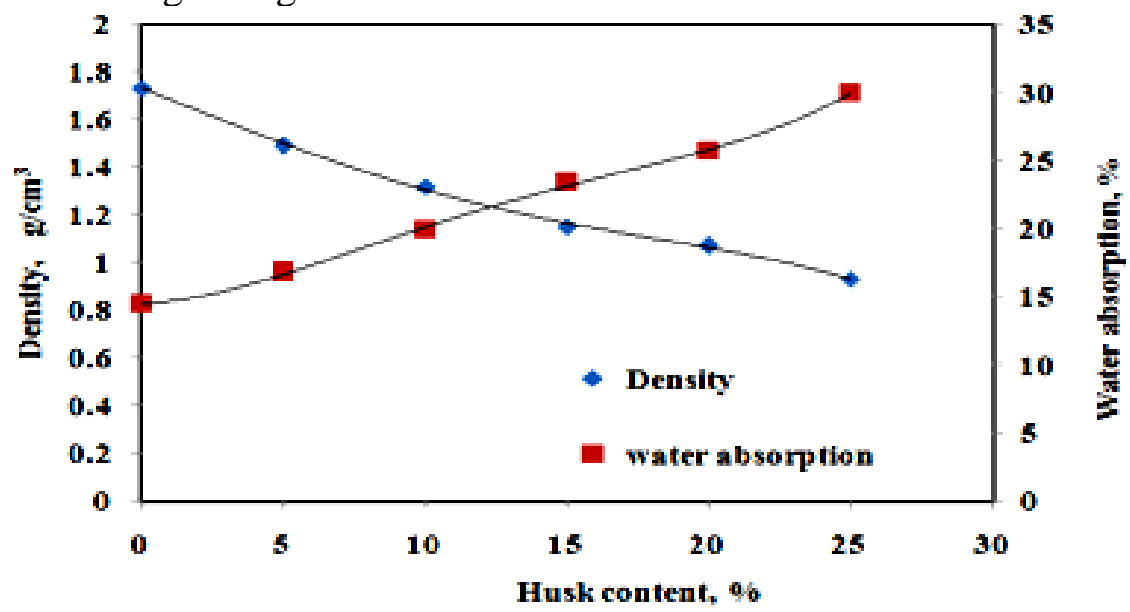

Fig. (9). Effect of rice husk, \% on the bulk density and water absorption of gypsum hardened binder after 28 day.

The degree of water absorption of mixture which contain rice husk is presented in Fig. 9. Comparing all the gypsum steel slag rice husk mixture to the control sample, it can be observed that the water absorption of rice husk mixtures increases with the amount of rice husk added into 
the mixture. The maximum value of water absorption was $30 \%$ at rice husk of $25 \%$, while the minimum value was $14.5 \%$ at rice husk of $0 \%$. Compared to the control sample, the increment of water absorption by $25 \%$ rice husk content is very high which is two times higher than that of control sample. In general, All gypsum steel rice husk mixtures show proportional relationship between density, compressive strength and water absorption.

\section{CONCLUSIONS}

This investigation was carried out to develop a composite from gypsum steel slag, and rice husk to make Eco-Friendly composite. Test results show that:

- The compressive strength for all tested hardened gypsum steel slag mixture increases with the increase of slag from 0 to $30 \%$, while resulted in decreasing compressive strength from 30 to $50 \%$ steel slag.

- The maximum value of compressive strength was $7 \mathrm{MPa}$ at curing time of 28 day for mixture contains steel slag of $30 \%$, while the minimum value was $1 \mathrm{MPa}$ at curing time of one day at steel slag of $50 \%$.

- Water resistance of gypsum matrix improved when steel slag content ranged from $30 \%$ to $50 \%$.

- Incorporating rice husk in gypsum steel slag mixtures decreasing compressive strength and density of the composite.

- The highest flexural strength of gypsum steel slag rice husk composite was observed up to $15 \%$ rice husk.

- Water absorption of gypsum steel slag rice husk composite increased by increasing husk content.

\section{REFERENCES}

Abuh N., and Umoh A.,2015. Palm kernel fruit fiber reinforced gypsumcement based wall panels: it's physical and mechanical characteristics, Pollution 1 (2)) 117-126.

Ashori A., 2017. Hybrid thermoplastic composites using nonwood plant fibers, Hybrid Polym. Compos. Mater. (3) 39-56.

Foaud، A. A. and F. Abdelradi, 2016. Analysis of the Rice Straw Recycling Value Added in Egypt Agricultural Economics. J. Agric. Econom. and Social Sci., Mansoura Univ., Vol. (11): 1039 - 1045.

Hekal, Abo-El-Enein.S, El-Korashy.S, Megahed. G, and El-Sayed. T, 2012. Hydration characteristics of Portland cement - Electricarc furnace slag blends, HBRC Journal 9, 118-124 
Henry, Alison, Stewart and John. (2011). Practical Building Conservation. Mortars, Renders \&Binders. Farnham Burlington: Ashgate. p. 87.

Hospodarova et al., 2018. Investigation of waste paper cellulosic fibers utilization into cement based building materials, Buildings 8(3) 43.

Khalil et al., Plaster composites modified morphology with enhanced compressive strength and water resistance characteristics, Constr. Build. Mater. 167 (2018) 55-64.

Pervyshin G., Yakovl G., Gordina A, Keriene J., Polyanskikh I., Fischer H., Rachimovad N., and Buryanove A.,2017. Water-resistant gypsum compositions with man-made modifiers, Procedia Engineering (172) $867-874$.

Ramesh et al., 2017. Plant fibre based bio-composites: sustainable and renewable green materials, Renew. Sust. Energy Rev. (79) 558584.

Rivera, R.X., C.A.Juarez-Alvarado and P. Valdez, 2012. Modified gypsum compounds: An ecological-economical choice to improve traditional binders, Construction and building materials 37, 591596.

Sagnak M., 2018. Stabilization of Bentonite and Kaolinite Clays using Recycled Gypsum and Liquid Sodium Silicate, Doctoral Dissertation, University of Delaware.

Saraswathy, V. and H. W. Song, Corrosion performance of rice husk ash blended concrete. Construction and Building Materials 21 (8) (2007) 1779-1784.

Selamat M., R. Hashim, O. Sulaiman, M. Kassim, N. Saharudin, O. Taiwo, 2019. Comparative study of oil palm trunk and rice husk as fillers in gypsum composite for building material, Construction and Building Materials (197) 526-532.

Weyer, A, R. Picazo, and Daniel. (2015). European Illustrated Glossary Of Conservation Terms For Wall Paintings And Architectural Surfaces. ISBN 978-3-7319-0260-7.

Zhu et al., Physical and mechanical properties of gypsum-based composites reinforced with PVA and PP fibers, Constr. Build. Mater. 163 (2018) 695-705. 


\section{الملخص العربي}

\section{الخصائص الزهنسيه لماده مركبه صديقة البيئة مصنوعة من الجبس و خبث الحديد و سرسه الأرز}

د/محمد إبرا هيم نصر مرسي' د/ هيثم حسين يوسف محمد؟

تهدف هذه الدر اسه الي معالجه خبث الحديد الناتج من صناعه الحديد و سرسه الارز كاحد اهم

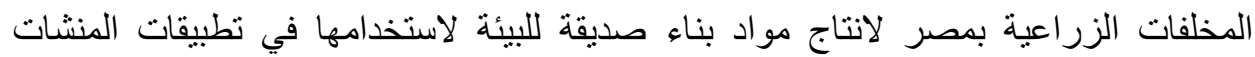
الزر اعية. تم تنفيذ التجارب علي ثلاث مر احل:

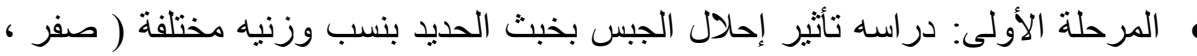

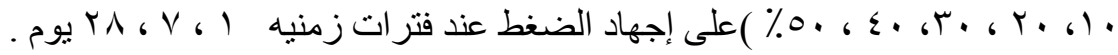
المرحله الثانية: در اسة تأثثر الغمر في الماء علي إجهاد الضغط لخلط لجبس وخبث الحديد.

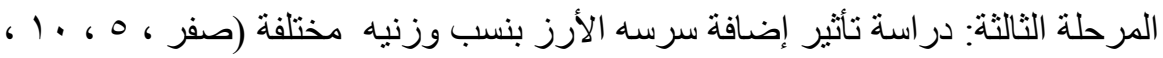

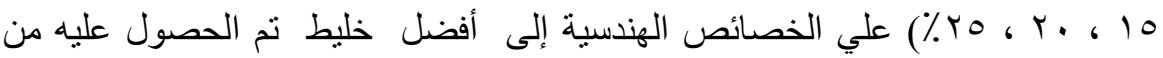
التجربتين السابقتين. تم در اسه الخصائص الهندية (إجهاد الضغط و إجهاد الانحناء و معدل امتصاص الماء وكثافة خليط الجبس و خبث الحديد و السرسه الارز) عند فتر ات زمنية مختلفه.

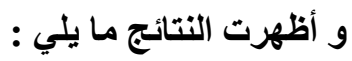

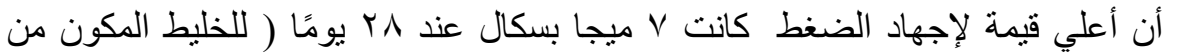

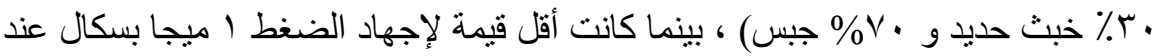

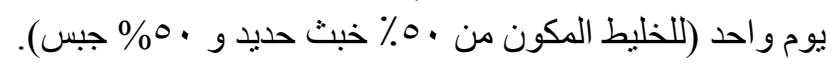
تحسنت مقاومه خليط الجبس وخبث الحديد للماء للخلطات التي تحتوي علي نسب خبث

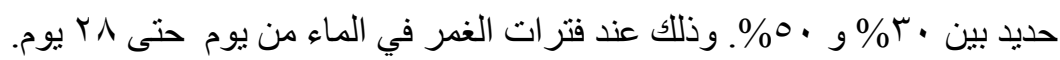

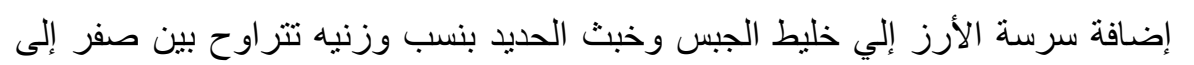

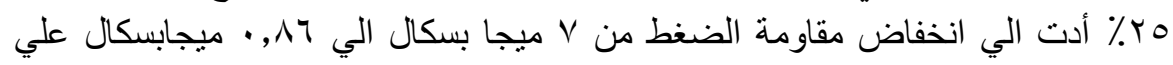
الترنيب • أظهرت النتائج تحسن اجهاد الانحناء لخليط الجبس وخبث الحديد بزيادة محتوي سرسه

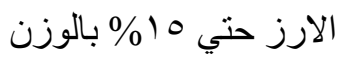

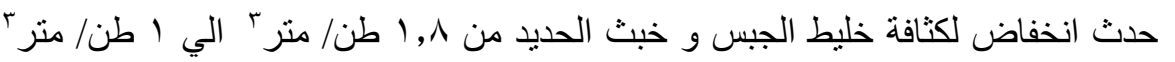

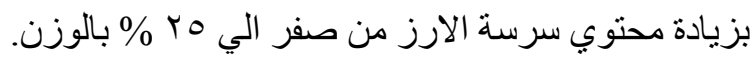

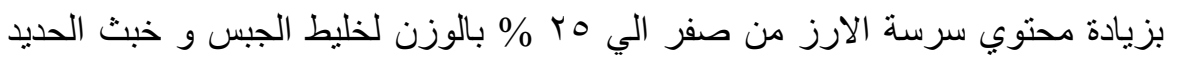

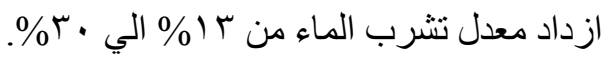

